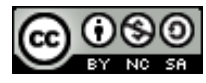

https://doi.org/10.31743/abmk.9827

PIOTR SZKUTNIK* - ŁÓDŹ

\title{
INWENTARZ RUCHOMOŚCI Z 1862 ROKU KS. ANDRZEJA CHYLIŃSKIEGO PROBOSZCZA PARAFII MĘKA W DEKANACIE SIERADZKIM
}

\section{Streszczenie}

Ksiądz Andrzej Chyliński był proboszczem parafii we wsi Męka pod Sieradzem, gdzie mieszkał razem z matką oraz zapewne ze służbą. Spisany po jego śmierci w 1862 r. inwentarz dzieli ruchomości na dwa tytuły, nie wyróżniając kategorii surowcowych.

Ruchomości wymienione w spisie posiadały funkcje kancelaryjne, wypoczynkowe, garderobiane, kulinarne, spiżarniane i gospodarcze. Mobiliów związanych z alkierzem było najwięcej. Mienie proboszcza z Męki liczyło łącznie 393, a po pominięciu ruchomości gospodarskich 366 sztuk zamieszczonych na 141 pozycjach inwentarza.

Porównanie majątku osobistego plebana z Męki wykazuje znaczną przewagę ilościową w większości rodzajów ruchomości w stosunku do liczby rzeczy okolicznego dziekana z początku XIX wieku (łącznie 129 sztuk) oraz inwentarzy plebanów staropolskich (108 sztuk). Odwrotną zależność można zaobserwować porównując mobilia A. Chylińskiego z ruchomościami zamożnego miejskiego rzemieślnika z Zamościa z połowy XIX wieku (599 sztuk). Pleban z Męki posiadał też nieco mniej srebrnych łyżek niż porównywane zbiorowości. Najdroższe ruchomości w inwentarzu z 1862 r. stanowiły 15\% sztuk rzeczy, a najtańsze 6\% wszystkich. Rzeczy drogich było zatem ponad dwa razy więcej niż tanich. Przedmioty określone jako „stare” stanowiły 13\% ogółu.

Słowa kluczowe: inwentarze rzeczy; ruchomości; historia Kościoła; Męka; XIX w.

Celem artykułu jest przedstawienie dobytku w postaci mienia ruchomego proboszcza parafii Męka pod Sieradzem. Wgląd w stan posiadania duchownego

\footnotetext{
* Piotr Szkutnik - adiunkt w Instytucie Historii, Uniwersytet Łódzki; e-mail: pszkutnik@poczta.onet.pl https://orcid.org/0000-0001-6086-2655
} 
umożliwia inwentarz zarejestrowany w aktach notarialnych, który stanowi przykład wykazu ruchomości administratora relatywnie dużej wiejskiej parafii. Na jego podstawie podjęto próbę uporządkowania przedmiotów duchownego według ich funkcji, porównania liczby rzeczy z danymi z innych przekazów, ustalenia proporcji mobiliów drogich, tanich oraz ,starych”.

\section{Proboszcz - wlaściciel ruchomości}

Urodzony w Lubrańcu 1799 r. Andrzej Chyliński po nauce w seminarium duchownym we Włocławku został wyświęcony na księdza i był duszpasterzem kolejno w Mstowie, Przystajni, Wilkowiecku, Mierzynie, Woli Grzymalinie, Wąsoszu․ W latach 1843-1862 administrował parafią Męka w dekanacie sieradzkim². Od 1858 r. był kanonikiem honorowym kaliskim³ ${ }^{3}$ Zmarł w Męce 17 czerwca 1862 r. $^{4}$

W skali dekanatu parafia Męka była relatywnie duża. W 1861 r. liczyła 2180 parafian. Jedynie 5 na 15 parafii w dekanacie sieradzkim liczyło w tym okresie ponad 2000 wiernych. Stołeczna parafia (Sieradz) liczyła wówczas 3970 parafian, a druga pod względem wielkości (Brzeźnio) 3012, gdzie również administrował kanonik honorowy kaliski. Do najmniejszej parafii w dekanacie (Dąbrowa Wielka) należało 408 katolików5. Dochody wiążące się z posługą kapłańską, w tym wpływy z tzw. iura stolae, zależały od liczby parafian, co miało wpływ na możliwości finansowe duszpasterza.

\section{Inwentarz mienia - „świat rzeczy"}

Ruchomości zapisane $\mathrm{w}$ testamentach ${ }^{6}$, intercyzach ${ }^{7}$, a przede wszystkim $\mathrm{w}$ inwentarzach stanowią swego rodzaju zwierciadło dawnej codzienności ${ }^{8}$. In-

${ }^{1}$ Archiwum Diecezjalne we Włocławku (dalej: ADWł), Akta diecezji kujawsko-kaliskiej, Archiwum Konsystorza Generalnego Włocławskiego, Akta personalne, Akta ks. Andrzeja Chylińskiego (1799-1862), k. 1.

${ }^{2}$ W. Kujawski, Kościelne dzieje Sieradza, Włocławek1998, s. 164; tenże, Diecezja kujawsko -kaliska. Opracowanie historyczno-źródłoznawcze, Włocławek 2011, s. 584; tenże, Parafie diecezji włocławskiej. Okres kujawsko-kaliski 1818-1925. Dla upamiętnienia 90. rocznicy powstania Towarzystwa Teologicznego we Włocławku, Włocławek 2018, s. 334-338.

${ }^{3}$ Ordo divini offici ad usum dioecesis Vladislaviensis seu Calissiensis pro anno domini 1859..., Warszawa [1858], s. 19.

${ }^{4}$ Archiwum Państwowe w Łodzi (dalej: APŁ), Akta stanu cywilnego (dalej: ASC) Męka, sygn. 112, Akt zgonu nr 43.

${ }^{5}$ Ordo divini offici ad usum dioecesis Vladislaviensis seu Calissiensis pro anno domini 1862 ..., Warszawa [1861], s. 19-20.

${ }^{6}$ P. Szkutnik, Testament mieszczanki szadkowskiej Doroty Czygańskiej z Lipińskich z 1693r., „Biuletyn Szadkowski”, 14 (2014) s. 97-112.

${ }^{7}$ A. Szykuła, Dwory ziemiańskie i garderoba ziemianek Zamojszczyzny na podstawie inwentarzy notarialnych z lat 1835-1876, , Kwartalnik Historii Kultury Materialnej” (dalej: KHKM), 56 (2008) nr 1, s. 20.

${ }^{8}$ R.-E. Mohrmann, Pośmiertne inwentarze mienia - krytyka źródta, problemy badawcze, KHKM, 53 (2005) nr 2 s. 143. 
stytucja notariatu w XIX wieku umożliwiła na większą skalę rejestrację mienia w postaci inwentarzy pośmiertnych, które były często przedmiotem licytacji ${ }^{9}$. $\mathrm{W}$ aktach notarialnych z tego okresu powstawały zapisy dotyczące wszystkich grup społeczeństwa, w tym również duchowieństwa.

Duchowny katolicki poza majątkiem kościelnym, którym administrował jako rządca parafii, posiadał również swój własny prywatny w postaci np. ruchomości. Zabezpieczenie czwartej części majątku zmarłego kapłana przypadającej Kościołowi wymagało spisania mienia księdza, dzięki czemu powstawały inwentarze ${ }^{10}$, które pozwalają na zorientowanie, jakimi przedmiotami otaczał się zmarły ${ }^{11}$. Świadczą one o standardzie jego życia ${ }^{12}$, stopniu zamożności, zapleczu pracy zawodowej, ubiorze, zainteresowaniach, kulturze stołu i mieszkania ${ }^{13}$. Pośmiertne inwentarze mienia duchownych spisywane w XIX wieku są nadal w niewystarczającym stopniu wykorzystanym źródłem do poznania zaplecza materialnego administracji kościelnej ${ }^{14}$.

Po śmierci A. Chylińskiego inwentarz jego ruchomości spisano 2-3 lipca $1862 \mathrm{r}^{15}, \mathrm{tj}$. w ciągu dwóch dni ${ }^{16}$. Struktura opisu ruchomości wynikała z tzw. niemieckiego systemu wyliczającego ruchomości według rodzajów ${ }^{17}$. W inwentarzach zwykle tworzono tabelaryczne spisy przedmiotów, w ramach grup, tzw. tytułów ${ }^{18}$. Ruchomości proboszcza z Męki opisano jedynie w dwóch. „Tytuł I Ruchomości domowe” liczy 96 pozycji, a „Tytuł II Garderoba, bielizna i pościel” liczy 45 pozycji. Łącznie inwentarz zawiera 141 pozycji. Niejednokrotnie jedna pozycja wymienia więcej niż jeden przedmiot ${ }^{19}$. Konstrukcja wykazu nie jest w pełni uporządkowana. Przedmioty są częściowo przemieszane. Nie ma numera-

${ }^{9}$ E. Mazur, Wykorzystanie inwentarzy w badaniach nad kultura XIX wieku na ziemiach polskich, KHKM, 51 (2003) nr 2, s. 178.

${ }^{10} \mathrm{~K}$. Lewalski, Inwentarz mienia - źródło do badań nad majątkiem osobistym duchowieństwa parafialnego w Królestwie Polskim na przetomie XIX i XX w., KHKM, 65 (2017) nr 2, s. 257-259.

${ }^{11}$ P. Szkutnik, [rec.] Duchowni na plebanii $i$ w drodze. Konteksty codzienności i interpretacje historyczne, red. K. Lewalski, A. Łysiak-Łątkowska, Gdańsk 2015, „, Archiwa Biblioteki i Muzea Kościelne" (dalej: ABMK), 110 (2018) s. 507-517.

${ }^{12}$ A. Moczulska, Inwentarze, protokoty licytacji, intercyzy i testamenty zawarte $w$ aktach notarialnych z obszaru Królestwa Polskiego w XIX wieku, „Studia Źródłoznawcze”, 22 (1977) s. 224.

${ }^{13}$ A. Klonder, D. Główka, Inwentarze mienia w badaniach kultury Europy od średniowiecza po nowożytność, KHKM, 51 (2003) nr 2, s. 164, 168.

${ }^{14} \mathrm{~K}$. Lewalski, Inwentarz mienia - źródto do badań nad majątkiem osobistym duchowieństwa parafialnego w Królestwie Polskim na przełomie XIX i XX w., KHKM, 65 (2017) nr 2, s. 257-259.

${ }^{15}$ APŁ oddział Sieradz (dalej: APŁoS), Akta notariusza J. Sikorskiego w Szadku, sygn. 8, nr 212 z 1862 r.

${ }^{16}$ Dobytek osób zamożnych inwentaryzowano nawet kilka tygodni. Zob.: Klonder, Główka, Inwentarze, s. 163.

${ }^{17}$ Mazur, Wykorzystanie, 2, s.177-178.

${ }^{18}$ A. Moczulska, Inwentarze, s. 219.

${ }^{19} \mathrm{~W}$ majątku sąsiedniego kanonika i dziekana z Szadku z początku XIX wieku inwentarz przedmiotów mieścił się w „Tytule IV Różne ruchomości”, gdzie w numeracji ciągłej wyliczono 83 pozycje z podziałem na grupy: pościel, bielizna, suknie, srebro, cyna, różne rzeczy i obrazy. Zob.: APŁoS, Akta notariusza A. Pstrokońskiego w Sieradzu, sygn. 4, k. 378-380. 
cji ciągłej wszystkich ruchomości, a jedynie w ramach tytułów ${ }^{20}$. Drugi tytuł wylicza w większości rzeczy przyporządkowane tam według zastosowania/funkcji. W inwentarzu brak jednak podziału na tworzywo/materiał. Czasami również brak określenia surowca, z jakiego są wykonane niektóre butelki czy naczynia.

\section{„Tytuł I Ruchomości domowe"21}

1. czarna politurowana kanapa brzozowa, podarta, kryta „bronelą”22 (6 rb. $\left.{ }^{23}\right)$; 2. sześć krzesełek „, Z tegoż garnituru” (3 rb. 60 kop.); 3. stolik ,przed kanapowy" z klapami (2 rb.); 4. stare krzesełko, popsute z wysoką poręczą (50 kop.); 5. dwa narożnikowe stoliki brzozowe (1 rb. 50 kop.); 6. stolik ,pod lustrowy” ( $2 \mathrm{rb}$.); 7. stare łóżko politurowane ( $2 \mathrm{rb}$.); 8. biała szafa spiżarniowa (2 rb.); 9. dwa „lanszafty" ${ }^{24} \mathrm{z}$ wyobrażeniem Chrystusa i Maryi w czarnych ramach za szkłem (1 rb.); 10. mały „ordynaryjny” stoliczek (30 kop.); 11. lichtarz z ,umbrelką"25 (15 kop.); 12. zegar stołowy (4 rb.); 13. skrzypce z pudłem (2 rb.); 14. dwa stare mosiężne lichtarze (30 kop.); 15 . nowa ręczna piłka (18 kop.); 16. pudło „łubowe"26 (10 kop.); 17. stary parasol i ,prawidła” oraz miotełka do sukien (15 kop.); 18. stary kuchenny stół (15 kop.); 19. wysuwany stół jadalny (1 rb. 30 kop.); 20. magiel (1 rb.); 21. „laterka” blaszana 27 (5 kop.); 22. cztery większe i trzy mniejsze „barełki”28 (75 kop.); 23. „,szafarnia”29 (1 rb.); 24. blaszana miednica (60 kop.); 25. samowar (1 rb.); 26. blaszana puszka do cukru (30 kop.); 27. nożyczki do papieru i szczypce (15 kop.); 28. cyrkiel, kałamarz, ,pieszczniczka” ${ }^{30}$ i pudełka (15 kop.); 29. stare żelastwo (30 kop.); 30. „kłoda” z żela-

${ }^{20}$ Inwentarz rzemieślnika z połowy XIX wieku posiada numerację ciągłą dla wszystkich 11 tytułów, gdzie łącznie podano 197 pozycji, 7 tytułów dotyczy ruchomości wyliczonych na 193 pozycjach. Zob.: A. Szykuła, Inwentarz rękawicznika z Zamościa Józefa Serwetowicza z roku 1857, KHKM, 56 (2008) nr 2, s. 219-226.

${ }^{21} \mathrm{~W}$ określeniach poszczególnych ruchomości, w stosunku do zapisu w inwentarzu, zmieniono szyk, zwykle umieszczając przymiotnik na początku oraz modernizując pisownię (np. zmieniając zapis z „żelaznemi” na „żelaznymi”). W cudzysłowiu podano te cytowania źródłowe, które stanowią charakterystyczne dla epoki terminy, obecnie powszechnie niefunkcjonujące.

${ }^{22}$ Może brokatela-rodzaj ciężkiej tkaniny, przetykanejjedwabiem.Zob. Inwentarzemieszczańskie z lat 1528-1635 z ksiag miejskich Poznania, wyd. S. Nawrocki, J. Wisłocki, Poznań1961, s. 568.

${ }^{23}$ Skrót nazwy waluty: rb. - rubel, kop. - kopiejka.

${ }^{24}$ Landszaft - obraz przedstawiający zwykle pejzaż. Zob.: W. Doroszewski, Słownik języka polskiego, t. 1-11, Warszawa 1958-1969 [wersja elektroniczna].

${ }^{25}$ Umbrelka - rodzaj osłony do palących się świec. Zob. tamże.

${ }^{26}$ Łubowe - wykonane z łyka, lipy. Zob. tamże.

${ }^{27}$ Blaszana latarka występuje np. w edycji E. Danowskiej, O rzeczach doczesnych księdza kanonika. Inwentarz pośmiertny Michała hrabiego Ankwicza z 1786 r., „Nasza Przeszłość”, 110 (2008) s. 125.

${ }^{28}$ Baryłka - pękata beczka. Zob. Słownik języka polskiego, red. J. Karłowicz, A.A. Kryński, W. Niedźwiedzki, t. 1, Warszawa 1900, s. 102.

${ }^{29}$ Szafarnia - spiżarnia, spichlerz. Zob. Doroszewski, Słownik, [wersja elektroniczna].

${ }^{30}$ Piaseczniczka - naczyńko lub puszka z piaskiem do zasypywania świeżo napisanego atramentem tekstu. Zob. tamże. 
znymi obręczami (1 rb.); 31. dwa „sądki” "31 (30 kop.); 32. „,́́wierć” do zboża (45 kop.); 33. prasa do mięsa (45 kop.); 34. balia z żelaznymi obręczami (30 kop.); 35. sieć do łapania ryb (2 rb.); 36. „ordynaryjne” łóżko (20 kop.); 37. „tłomak”32 do pościeli (60 kop.); 38. prasa od sera (30 kop.); 39. siedem „szaflików”33 (10 kop.); 40. flet (30 kop.); 41. „faska” ${ }^{34}$ (15 kop.); 42. żelazne garnki różnej objętości (1 rb. 50 kop.); 43. „misnik” ${ }^{35}$ i szafka do garnków (15 kop.); 44. pięć „,solówek”"36 (15 kop.); 45. trzy blaszane brytwanny (30 kop.); 46. 24 sztuki „ordynaryjnych" talerzy porcelanowych (1 rb.); 47. trzy salaterki (60 kop.); 48. pięć filiżanek (5 kop.); 49. osiem szklanek (15 op.); 50. trzy fajansowe talerze, dwa szklane talerzyki, cztery kieliszki do wina (15 kop.); 51. fajansowa waza, blaszana cukierniczka, pieprzniczka, dwa durszlaki, cztery blaszane łyżki, łyżka wazowa, żelazny moździerz, tartka ( 2 rb.); 52. dwa czajniki, durszlaczek z rączką, łyżka wazowa, ,półkwaterek”, małe pudełko do kawy, miarka do kawy, maszynka do gotowania kawy z białej blachy (30 kop.); 53. duża karafka, dwa kufelki i kryształowa „rżnięta” szklanka (60 kop.); 54. młynek do kawy (3 kop.); 55. połowa „wyprawnej” skóry świńskiej (60 kop.); 56. przetak, sito, „łamki”"37 do lnu, szczotki

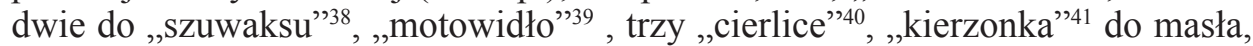
faska do mąki z żelaznymi obręczami (1 rb.); 57. dwie „,dynarki” ${ }^{42}$, rożen, pogrzebacz, dwie żelazne pokrywki, piecyk do kawy, blaszana patelka (60 kop.); 58. Siekacz, „dzirzka”43, okuty „,szkopek”44 (10 kop.); 59. piła „tracka” (60 kop.);

${ }^{31}$ Sądek - naczynie drewniane u góry węższe, naczynie do zlewania mleka lub barszczu, baryłka, beczułka. Zob.: Stownik języka polskiego, t. 6, Warszawa 1909, s. 38.

${ }^{32}$ Thumok - worek na pościel. Zob. A. Brzeska, Inwentarze wypraw ślubnych kobiet $z$ rodu Jagiellonów jako źródło do poznania wyposażenia wnętrz dworskich, KHKM, 56 (2008) nr 1, s. 11.

${ }^{33}$ Szaflik - naczynie okrągłe, zwykle drewniane, z jednym, dwoma uchami, używane w gospodarstwie i murarstwie do zaprawy. Zob. Doroszewski, Stownik, [wersja elektroniczna].

${ }^{34}$ Faska - naczynie drewniane z klepek, zwężone u dołu do przechowywania produktów. Zob. tamże.

${ }^{35}$ Misnik - szafa lub półki na miski, też podkładka pod misę na stole i naczynie, w którym się myje miski. Zob. tamże.

${ }^{36}$ Solówka - beczka do soli. Zob. tamże.

${ }^{37}$ Łamka, łamanka - przyrząd do łamania lnu. Zob. Słownik języka polskiego, t. 2, Warszawa 1902, s. 793.

${ }^{38}$ Szuwaks - czarna pasta do czyszczenia butów. Zob. Doroszewski, Słownik, [wersja elektroniczna].

${ }^{39}$ Motowidło - przyrząd służący do odmierzania i zwijania w motki nici, przędzy i szpagatu. Zob. tamże.

${ }^{40}$ Cierlica - przyrząd do oczyszczania lnu z paździerzy. Zob. tamże.

${ }^{41}$ Kierzanka - drewniane naczynie w kształcie konewki z tłokiem, służące do wyrobu masła, maślnica. Zob. tamże.

${ }^{42}$ Dynarek - żelazna konstrukcja nad ogniem w kominku, na której stawia się garnek. Zob. tamże.

${ }^{43}$ Dziżka, dzieżka - naczynie do wyrabiania ciasta na chleb, do przechowywania nabiału, faska, naczynie gliniane bez ucha. Zob. Słownik gwar polskich, wyd. J. Karłowicz, t. 1, Kraków 1900, s. $438,447$.

${ }^{44}$ Szkopek - naczynie drewniane w kształcie wiaderka z jednym uchem, używane najczęściej przy dojeniu, dojnica, skopek. Zob. Doroszewski, Stownik, [wersja elektroniczna]. 
60. osiem noży z drewnianą oprawą, 10 widelców (45 kop.); 61.16 butelek (15 kop.); 62. dwa szpadle (15 kop.); 63. po pięć funtów sadła i słoniny (1 r.); 64. 16 garncó ${ }^{45}$ grochu polowego, dwa garnce grochu tyczkowego (1 rb. 25 kop.); 65. 16 garnców mąki żytniej ( $1 \mathrm{rb}$.); 66. trzy korce ${ }^{46}$ jęczmienia $(6 \mathrm{rb}$.); 67. 16 garnców owsa (1 r.); 68. cztery korce starych zrośniętych kartofli (1 rb.); 69. dwa ordynaryjne koszyki (6 kop.); 70. dwie pary okularów „,oprawnych” w srebro oraz stal, stara brzytwa i pasek do ostrzenia brzytwy (1 rb. 50 kop.); 71 . ważąca trzy łuty srebrna, stara tabakiera (3 rb.); 72. pół beczki soli (4 rb.); 73. cztery srebrne łyżki i jedna do kawy „próby jedenastej” ważące 13 łutów (7 rb. 80 kop.); 74. łańcuch z kompozycji „,W ogniu" pozłacany do noszenia dystynktorium ${ }^{47}(12 \mathrm{rb}$.); 75. dystynktorium (6 rb.); 76. krzyż metalowy z wstążką św. Włodzimierza na pamiątkę wojny z lat $1853 / 56^{48}$ (15 kop.); 77 . złoty pierścień z „koronnego” złota bez środkowego kamienia (1 rb.); 78. pięć miedzianych rondli ważących 15 funtów (4 rb. 50 kop.); 79. dwa funty herbaty ( $2 \mathrm{rb}$.); 80 . pulwersak ${ }^{49}$ oraz dwa rogi (5 kop.); 81. młoteczek, pilniczek, świderek, szczypczyki i pieczątka (5 kop.); 82. dwie laski laku (3 kop.).

\section{„Porządki gospodarcze i inwentarze”}

83. stary „młynik” do zboża (3 rb.); 84. dwie żelazne brony (3 rb.); 85. lada do sieczki z kosą, babką i młotkami (1 rb.); 86. pięć jesionowych oraz sześć sosnowych tarcic ( 3 rb.); 87.nie okuty wóz (2 rb. 45 kop.); 88. pług bez żelastwa ( 80 kop.); 89. nie okute dwa kółka do pługa (40 kop.); 90. czarna krowa z „odmianą” białą pod brzuchem (26 rb.); 91. czarna krowa z białymi „odmianami” (28 rb.); 92. czarna krowa $\mathrm{z}$ „odmianą" białą na nogach (15 rb.); 93. łysa, czarna jałówka (9 rb.); 94. łysa, czarna jałówka (9 rb.); 95. czerwona jałówka z białymi „odmianami”" (13 rb.); 96. cztery siągi ${ }^{50}$ drzewa (4 rb.).

${ }^{45}$ Garniec nowopolski jako miara pojemności ciał sypkich w latach 1819-49 wynosił 4 litry. Zob. I. Ihnatowicz, A. Biernat, Vademecum do badań nad historia XIX i XX wieku, Warszawa 2003, s. 50 .

${ }^{46}$ Korzec nowopolski jako miara pojemności ciał sypkich w latach 1819-49 wynosił 128 litry. Zob. tamże.

${ }^{47}$ Dystynktoria - małe ordery noszone na łańcuchu przez kanoników, posiadały wyobrażenie orła białego oraz patrona kościoła katedralnego. Zob. J. Kitowicz, Opis obyczajów i zwyczajów za panowania Augusta III, t. 1, wyd. E. Raczyński, Poznań1840, s. 169-170.

${ }^{48}$ Krzyż świadczył o lojalnej postawie księdza wobec zaborcy. Specjalny krzyż dla duchowieństwa przyznawany przez cesarza Aleksandra II na pamiątkę wojny krymskiej o wymiarach $100 \times 60 \mathrm{~mm}$. z brązu został wybity w liczbie 40 tys. sztuk. Zob. W. Jakubowski, Ordery i medale Rosji, Toruń 1993, s. 139-140, 210.

${ }^{49}$ Pulwersak - worek skórzany na śrut. Zob. Doroszewski, Słownik, [wersja elektroniczna].

${ }^{50}$ Możliwe, że chodzi o siąg krakowski jako miarę drzewa opałowego w XIX wieku, który wynosił 2,8 $\mathrm{m}^{3}, 3,5 \mathrm{~m}^{3}$ lub $3 \mathrm{~m}^{3}$. Zob. Ihnatowicz, Biernat, Vademecum, s. 82. 


\section{„Tytuł II Garderoba, bielizna i pościel”}

1. granatowy płaszcz (12 r.); 2. Stary, „,Szaraczkowy”" ${ }^{1}$ płaszcz podbity futrem „szopowym” (20 r.); 3. stara sutanna podbita futrem zwanym „kasztany” (12 rb.); 4. surdut podbity czarnymi baranami (4 r.); 5. sukienna sutanna i atłasowy „paledron" 52 ( 8 rb.); 6. „,szaszedronowy” surdut (sutanna) (1 r.); 7. stary, zniszczony, czarny surdut (2 rb.); 8. stary, barchanowy szlafrok ${ }^{53}$ (30 kop.); 9. stare, ,,szaraczkowe" spodnie (15 kop.); 10. letni szary surdut (60 kop.); 11. dwie stare kamizelki (10 kop.); 12. stara czapka z futra bobrowego (3 rb.); 13. dwa stare kapelusze (30 kop.); 14. „półrokicie”54, obojczyk z paciorków, fioletowa wstążka ,anti morowa" 55 (50 kop.); 15. pas „morowy” z frędzlami „szychowemi” (10 kop.); 16. stary, „morowy” napierśnik ${ }^{56}$ (3 kop.); 17. biała, bawełniana „szlafmyca” ${ }^{57}$, kolorowe chustki do nosa (dwie niebieskie, jedna czerwona), dwie bawełniane „mankietki"58 (15 kop.); 18. „kortowy”, „szaraczkowy” kaszkiet (30 kop.); 19. „berlacze”59 kapeluszowe (10 kop.); 20. trzy pary starych butów (2 r.); 21. dwie pary flanelowych oraz pięć par płóciennych ,gatek” (1 rb.); 22.18 sztuk starych, płóciennych koszul (4 rb. 50 kop.); 23. sześć sztuk starych, podartych koszul (90 kop.); 24. dwie sztuki grubych, płóciennych prześcieradeł (60 kop.); 25.14 par „,szkarpetek” (50 kop.); 26. obrus i serweta (60 kop.); 27.15 sztuk kołnierzyków (20 kop.); 28. trzy poszewki na poduszki tj. jaśki (30 kop.); 29. popsuty, „w macicę oprawny” scyzoryk (5 kop.); 30. dwie kartonowe poszewki (30 kop.); 31. dwie poduszki (2 rb. 45 kop.); jedna poduszka; 32. bawełniany szalik (30 kop.); 33. stare pantofle (5 kop.); 34. stara kołdra (30 kop.); 35. gumowe kalosze (30 kop.); 36. cynowa kropielniczka $^{60}$ (3 kop.); 37. naszelniki i łańcuszek (30 kop.); 38. siekiera (45 kop.); 39. stary siennik (3 kop.); 40. bat i kij (10 kop.); 41. „serynga"61 (40 kop.); 42. blaszana tacka i szczypce (6 kop.); 43. papierowe pudełko, waga drewniana (1 rb.); 44. mosiężny kurek i mała piłeczka (30 kop.); 45. „oprawna” w skórę ołowianka $^{62}$ (30 kop.).

${ }^{51}$ Sukno szaraczkowe występuje w pierwszej połowie XIX wieku. Zob. J. Kobierzycki, Przyczynki do dziejów ziemi sieradzkiej, cz. 1, Warszawa 1915, s. 117.

${ }^{52}$ Paledra, palendron - rodzaj sukni księżej, sutanny bez guzików, rewerenda. Zob. Słownik języka polskiego, t. 4, Warszawa 1908, s. 17.

${ }^{53}$ Szlafrok - ubiór domowy. Zob. D. Główka, Majątek osobisty duchowieństwa katolickiego w Koronie w XVII i XVIII wieku, Warszawa 2004, s. 90.

${ }^{54}$ Półrokicie - szata w kształcie komży z obcisłymi rękawami. Zob. tamże, s. 76.

${ }^{55}$ Rokiety i wstążki, również fioletowe nosili kanonicy. Zob. tamże, s. 76.

${ }^{56}$ Wykonane z mory, czarne morowe wstążki, choć w tym znaczeniu elementy stroju zabezpieczające przed zarazą, tzw. morowym powietrzem. Zob. Doroszewski, Słownik, [wersja elektroniczna].

${ }^{57}$ Szlafmyca - miękka czapka męska. Zob. tamże; czapka nocna zob. Główka, Majątek, s. 94.

${ }^{58}$ Mankietki były stosowane do koszul i innych strojów. Zob. Główka, Majątek, s. 93.

${ }^{59}$ Berlacz, berlaczek - element garderoby, zapewne okrycia głowy. Zob. Doroszewski, Stownik.

${ }^{60}$ Kropielniczka służyła do wody święconej. Zob. Główka, Majątek, s. 182.

${ }^{61}$ Serynga, serenga - sikawka, strzykawka. Zob. Słownik języka polskiego, t. 6, Warszawa 1909, s. 76.

${ }^{62}$ Ołowianka - ciężarek ołowiany służący do mierzenia głębokości, pręt z ołowiu. Zob. Doroszewski, Stownik, [wersja elektroniczna]. 


\section{Podział ruchomości według funkcji}

Dom ks. A. Chylińskiego składał się z dwóch izb plebana oraz izby czeladnej z komorą. Miał dwa „zachowania" ${ }^{63}$. Był wyposażony w okiennice, zamki, klamki, rygle, kryty „szkudłami”" ${ }^{4}$. Proboszcz posiadał również murowany „sklep” ${ }^{65}$ na kartofle i włoszczyznę z również dwoma „zachowaniami”, wyposażony w drzwi oraz sufit. Ponadto probostwo dysponowało organistówką oraz budynkami gospodarczymi, jak stodoła, spichlerz, stajnia, obora i chlewiki ${ }^{66}$. W budynkach tych niewątpliwie znajdowały się przedmioty opisane w inwentarzu. Większość zapewne w samej plebanii, sprzęty wykorzystywane do prac rolniczych/ogrodniczych w budynkach gospodarskich. Możemy zakładać, że jedno z pomieszczeń w plebanii mogło pełnić funkcję pokoju gościnnego czy kancelarii, a drugie sypialni/alkierza wraz z garderobą. W izbie czeladnej mogła znajdować się kuchnia, a komora mogła pełnić funkcję spiżarni, obok sklepu przeznaczonego na warzywa, natomiast ,zachowania” stanowiły dodatkowe schowki.

Przedmioty wykorzystywane $\mathrm{w}$ inwentarzu, np. do przechowywania, konsumpcji czy wypoczynku ${ }^{67}$, można uporządkować według funkcji sugerującej lokalizację. W pokoju gościnnym/kancelarii mogły znajdować się meble służące do przyjmowania gości czy petentów: stoliki, krzesełka, obrus i serweta. Możliwe, że była tam biblioteczka ${ }^{68}$. Składały się na nią kazania kościelne, Pamiętnik religijno-moralny i inne publikacje służące do nabożeństw. Na ścianach zapewne wisiały landszafty. $Z$ drobnych przedmiotów mogła się tam znajdować kropielniczka cynowa. Na stołach stały dwa stare lichtarze mosiężne i pewnie zegar stołowy. Większość utensyliów kancelaryjnych prawdopodobnie trafiła do rąk następcy zmarłego ${ }^{69}$. W inwentarzu wykazano jedynie nożyczki do papieru, szczypce, cyrkiel, kałamarz, ,pieszczniczkę”, pudełka, młoteczek, pilniczek, świderek, szczypczyki, pieczątkę i dwie laski laku.

W sypialni zapewne ulokowano meble związane z wypoczynkiem: łóżka, kanapę, stoliki. Wyposażenie łóżek stanowiły prześcieradła, poszewki, poduszki, kołdra, siennik, „tłomak” do pościeli. W alkierzu mogły znajdować się bardziej intymne drobiazgi kapłana. Wśród nich „serynga” - jedyna pozostałość świad-

${ }^{63}$ Zachowanie - skład, skrytka, Zob. Słownik języka polskiego, t. 8, Warszawa 1923, s. 39.

${ }^{64}$ Szkudła - deseczka do pokrywania dachów, gont. Zob. Doroszewski, Słownik, [wersja elektroniczna].

${ }^{65}$ Sklep - pomieszczenie ze sklepieniem, piwnica. Zob.: Doroszewski, Stownik, [wersja elektroniczna].

${ }^{66}$ Inwentarz „fundi instructi” probostwa w Męce z 9 lipca 1862 r. Zob. ADWł, Akta parafialne, sygn. A. par. Męka 7, k. nlb. Por. P. Szkutnik, Siedziby dziekanów dekanatu brzeźnickiego w diecezji kujawsko-kaliskiej w XIX w., KHKM, 59 (2011) nr 2, s. 167-181.

${ }^{67}$ Klonder, Główka, Inwentarze, s. 168.

${ }^{68}$ Według inwentarza nieuporządkowana, niskiej wartości, przez co niewciągnięta do wykazu oraz nieotaksowana.

${ }^{69}$ P. Szkutnik, Utensylia $w$ kancelarii dziekana brzeźnickiego $w$ pierwszej połowie XIX $w$, „Archiwista Polski”,19 (2014) nr 3, s. 23-30. 
cząca o podjętym leczeniu. Przedmioty do zabiegów kosmetycznych ${ }^{70}$ : blaszana miednica, zapewne do mycia, kurek mosiężny, być może od zbiornika na wodę ${ }^{71}$. Przedmioty osobiste, jak dwie pary okularów oprawnych w srebro i stal, stara brzytwa i pasek do jej ostrzenia. Do oświetlenia służył lichtarz z „umbrelką”, blaszana latarka. Mogły tam być przechowywane sugerujące zainteresowania instrumenty muzyczne: skrzypce z pudłem, flet. W pierwszej połowie XIX wieku, podobnie jak w okresie staropolskim ${ }^{72}$, instrumenty muzyczne rzadko występowały na wiejskich plebaniach ${ }^{73}$. Możliwe, że w sypialni ksiądz przechowywał kosztowności (tabakierę, dystynktorium, pierścień) oraz pulwersak i dwa rogi sugerujące używanie broni palnej, może do polowania lub obrony ${ }^{74}$.

Garderobę kapłana stanowiły sutanny, półrokicie, obojczyk z paciorków, wstążka, pas, napierśnik. Na odzież wierzchnią składały się ponadto: płaszcze, surduty, kamizelki, spodnie, szlafrok, nakrycia głowy (czapki, kapelusze, kaszkiet, „,berlacze”, „szlafmyca”), obuwie (buty, pantofle, kalosze), bielizna (koszule, „gatki”, ,szkarpetki”, chustki do nosa). Uzupełnieniem odzieży były kołnierzyki, mankietki, naszelniki, łańcuszek, szalik. Wśród garderoby stał pewnie stary parasol i ,prawidła” oraz miotełka do sukien.

Kulinarne przeznaczenie posiadały niektóre stoły, szafki z naczyniami do przechowywania/przygotowywania potraw, zastawą stołową, sztućcami, kuchennymi sprzętami jak samowar, prasa do mięsa i sera, młynek do kawy, czajniki, siekacz, „dzirzka”, moździerz, tartka, maszynka do gotowania kawy, piecyk do kawy, „kierzonka” do wyrabiania masła, faska do mąki, szczypce, waga, „,ynarki”, rożen, pogrzebacz, pokrywki.

W spiżarni/sklepie znajdowała się szafa oraz pudełka, naczynia, butelki, beczki, koszyki. Przechowywano tam żywność, tj. sadło, słoninę, groch, mąkę żytnią, jęczmień, owies, kartofle, sól, herbatę.

W pomieszczeniu dla służby mógł się znajdować sprzęt do przędzenia nici, przetak, sito, szczotki do szuwaksu ${ }^{75}$, magiel, balia, piły, szpadle, siekiera, scyzoryk, bat i kij, sieć do łapania ryb. Zapewne poza plebanią znajdował się inwentarz martwy (wóz, brony, pług, ,młynik” do zboża, lada do sieczki z kosą, babką i młotkami oraz drzewo) oraz żywy (trzy krowy i trzy jałówki).

${ }^{70}$ A.R. Chodyński, Obyczajowość polska w świetle inwentarzy Czapskich z XVIII w., KHKM, 51 (2003) nr 2, s. 283.

${ }^{71}$ Zob. Główka, Majątek, s. 179.

${ }^{72}$ Skrzypce występują 4 razy na analizowane 342 przekazy z okresu staropolskiego. Zob. tamże, s. 188.

${ }^{73} \mathrm{~Np}$. klawiszowy instrument muzyczny u proboszcza wiejskiego Zob. S. Piątkowski, Niektóre elementy wyposażenia plebanii we wsi i miasteczku pótnocnej Małopolski w pierwszej połowie XIX wieku, „Studia Sandomierskie”, 9 ( 2002) s. 346.

${ }^{74}$ Główka, Majątek, s. 189.

${ }^{75}$ Szuwaks - czarna pasta do czyszczenia butów. Zob. Doroszewski, Słownik, [wersja elektroniczna]. 


\section{Liczba przedmiotów}

Inwentarz proboszcza Męki wymienia w 141 pozycjach 393 sztuk ruchomości. Oznacza to, że każda pozycja inwentarza rejestrowała średnio 2,8 sztuki danej rzeczy. Pomijając 6 sztuk trzody, 10 żywności, 3 opału, 8 sprzętu gospodarskiego czyli łạcznie 27 , liczba przedmiotów wynosi $366^{76}$. Dla porównania inwentarz miejskiego rzemieślnika z połowy XIX wieku na 193 pozycjach zawiera 599 sztuk ruchomości domowych oraz 659 sztuk wyrobów rzemieślniczych ${ }^{77}$. W inwentarzu dziekana Szadkowskiego z początku XIX wieku na 84 pozycjach znalazło się 129 sztuk rzeczy ${ }^{78}$. Liczba ruchomości w inwentarzach duchownych staropolskich to średnio $108^{79}$. W inwentarzu z Męki najliczniejsze są według liczby sztuk wśród garderoby 24 koszule i 15 kołnierzyków, wśród zastawy stołowej 24 talerze i 16 butelek, natomiast wśród mebli 7 krzeseł.

Porównanie liczby rzeczy w poszczególnych kategoriach ze wspomnianymi przykładami pozwala na ustalenie następujących proporcji: proboszcz Męki posiadał ponad cztery razy mniej mebli (17 sztuk) niż wspomniany zamożny miejski rzemieślnik $(72)^{80}$, podobną ich liczbę co okoliczny dziekan $(16)^{81}$ oraz trzy razy większą niż plebani staropolscy $(6 \text { do } 7)^{82}$; miał niemal trzy razy mniej garderoby (47) niż rzemieślnik $(128)^{83}$, jednocześnie niemal pięć razy więcej niż dziekan $(10)^{84}$ oraz dwa razy więcej niż duchowni staropolscy $(23)^{85}$; natomiast zastawy stołowej posiadał nieco więcej (86) niż rzemieślnik $(75)^{86}$, ponad dwa razy więcej niż dziekan $(37)^{87}$ oraz ponad trzy razy więcej niż staropolscy plebani $(26)^{88}$. Srebrnych łyżek ks. A. Chyliński miał mniej (5) niż rzemieślnik (9) ${ }^{89}$ oraz dzie$\mathrm{kan}^{90}$ i plebani staropolscy ${ }^{91}$ (po 7). Srebrna zastawa rzadko gościła na stołach wiejskich plebanii w pierwszej połowie XIX wieku ${ }^{92}$. Ks. A. Chyliński posiadał złoty pierścień oraz srebrną tabakierę, a jako kanonik złote dystynktorium. Ple-

${ }^{76} \mathrm{~W}$ przypadku garderoby parę liczono jako jedną sztukę, odnośnie zapasów żywności dany produkt liczono również jako jedną sztukę. Inwenarz A. Chylińskiego nie zawierał książek, stąd nie są uwzględnione w podanej liczbie sztuk.

${ }^{77}$ Szykuła, Inwentarz, s. 219-226.

${ }^{78}$ Bez książek, trzody, sprzętów gospodarskich i żywności, których nie wymienia. Zob. APŁoS, Akta notariusza A. Pstrokońskiego w Sieradzu, sygn. 4, k. 377-380v.

${ }^{79}$ Liczba rzeczy nieuwzględniająca książek. Zob. Główka, Majątek, s. 52.

${ }^{80}$ Szykuła, Inwentarz, s. 219-226.

${ }^{81}$ P. Szkutnik, Ksiadz Michat Mieczko Żdzenicki (1744-1814) proboszcz i dziekan szadkowski, „Przegląd Nauk Historycznych”, 14 (2015) nr 1, s. 182.

${ }^{82}$ Główka, Majątek, s. 122, 125, 202, 203.

${ }^{83}$ Szykuła, Inwentarz, s. 219-226.

${ }^{84}$ Wliczono tu czarne suknie. Zob. Szkutnik, Ksiadz, s. 179, 183-184.

${ }^{85}$ Główka, Majątek, s. 68, 91,96.

${ }^{86}$ Szykuła, Inwentarz, s. 219-226.

${ }^{87}$ Szkutnik, Ksiadz, s. 183.

${ }^{88}$ Główka, Majątek, s. 163.

${ }^{89}$ Szykuła, Inwentarz, s. 219-226.

${ }^{90}$ Szkutnik, Ksiadz, s. 183.

${ }^{91}$ Główka, Majątek, s. 202.

${ }^{92}$ Piątkowski, Niektóre, s. 352-353. 
bani staropolscy również posiadali średnio jedną tabakieręę oraz jak okoliczny dziekan $^{94}$ jeden sygnet ${ }^{95}$.

Proboszcz Męki posiadał najbardziej popularne w okresie staropolskim dwa wizerunki Chrystusa i Maryi. Plebani z północnej Małopolski w XIX wieku gromadzili po kilkanaście, a nawet 40 mniejszych obrazków oraz kilka- kilkanaście obrazów religijnych ${ }^{96}$, podobna liczba obrazów występuje w inwentarzu miejskiego rzemieślnika $(42)^{97}$.

\section{Rzeczy drogie, tanie, stare}

Otaksowanie ruchomości było dokonywane przez taksatora ${ }^{98}$, którym w Męce został Idzi Drzewiecki, nauczyciel miejscowej szkoły elementarnej ${ }^{99}$, zapewne wykazujący się biegłością w rachunkach. Wartość rzeczy określana przez biegłego wynikała z jego orientacji w cenach rynkowych.

Najdroższe ${ }^{100}$ rzeczy o wartości od 3 do 28 rubli zarejestrowano w 27/141 pozycjach inwentarza. Liczyły łącznie 59/393 sztuk, czyli stanowiły $15 \%$ wszystkich ruchomości zawartych w inwentarzu. W inwentarzu w „Tytule I ruchomości domowe" wyliczono 96 pozycji, których wartość oszacowano na 222 rb. 35 kop. Spośród nich najdroższe rzeczy znajdowały się na 20 pozycjach o łącznej wartości 169 rb. 90 kop. Stanowiły zatem 76\% wartości wszystkich rzeczy zawartych w tym tytule, zajmując jedynie jego $28 \%$ pozycji. Były to meble (6 krzesełek $3 \mathrm{rb}$. 60 kop.; zegar 4 rb.; kanapa 6 r.), przedmioty ze szlachetnych kruszców (srebrna tabakiera 3 r.; pięć srebrnych łyżek 7 rb. 80 kop.; dystynktorium 6 rb.; pozłacany łańcuch 12 r.). zapasy żywności oraz opału/budulca (pół beczki soli 4 r.; trzy korce jęczmienia 6 rb.; tarcice 3 rb., drzewo 4 r.), sprzęt (brony 3 rb.; stary młynik do zboża 3 rb.; 15 rondli miedzianych 4 rb. 50 kop.), inwentarz żywy (3 krowy po 15 rb., 26 rb. i 28 rb. oraz 3 jałówki po 9 rb. i 13 rb.). Wśród najdroższych wyróżnia się żywy inwentarz (6 krów) wymieniony w sześciu pozycjach oszacowany na $100 \mathrm{rb}$. i jako jedyna kategoria mieszcząca się w całości wśród ruchomości drogich. Przedmioty ze szlachetnych metali zawarte w czterech pozycjach były warte 28 rb. 80 kop., czyli niewiele więcej niż najdroższa krowa (28 rb.). Najdroższe meble zapisane na 4 pozycjach były razem warte jedynie $19 \mathrm{rb} .60$ kop. W ,tytule II Garderoba, bielizna i pościel” wartość przedmiotów wyliczonych na 45 pozycjach oszacowano na $81 \mathrm{rb}$. 40 kop. Najdroższe spośród nich znalazły się na siedmiu pozycjach o wartości $63 \mathrm{rb}$. i $50 \mathrm{kop}$. Stanowiły zatem $78 \%$ wartości wszystkich rzeczy zawartych w tym tytule, zajmując jedynie jego $15 \%$ pozycji.

\footnotetext{
${ }^{93}$ Moda na zażywanie tabaki i tabakiery pojawia się w XVIII wieku. Zob. D. Główka, Majątek, s. 102 .

${ }^{94}$ Szkutnik, Ksiadz, s. 187.

${ }^{95}$ Główka, Majątek, s. 203.

${ }^{96}$ Piątkowski, Niektóre, s. 346-349.

${ }^{97}$ Szykuła, Inwentarz, s. 219-226.

${ }^{98}$ Mohrmann, Pośmiertne, s. 140.

${ }^{99}$ APŁoS, Akta notariusza J. Sikorskiego w Szadku, sygn. 8, nr 212 z 1862 r., k. 353v.

${ }^{100}$ Przyjęto 100-krotność wartości najtańszej rzeczy. Uwzględniono jako najdroższe wszystkie rzeczy z pozycji wycenionej na co najmniej 3 ruble.
} 
Były to dwa płaszcze po 12 rb. i 20 r., dwie sutanny po 12 rb. i 8 rb.; surdut za 4 rb.; czapka 3 rb. oraz 18 koszul 4 rb. 50 kop. Najdroższe składniki majątku plebana z Męki to: krowa (28 rb.), płaszcz z futrem „szopowym” (20 rb.), oraz łańcuch (12 rb.). W staropolskich inwentarzach księży najbardziej wartościową częścią majątku była odzież ${ }^{101}$, która przy nieuwzględnieniu inwentarza żywego, również u ks. A. Chylińskiego jest najdroższa.

Najtańsze ruchomości ${ }^{102}$ o wartości od 3 do 6 kopiejek zanotowano w 13/141 pozycji inwentarza. Liczyły łącznie sztuk 26/393, czyli 6\% sztuk wszystkich ruchomości zawartych w inwentarzu. Wśród nich znajdowały się rzeczy stare i ,prostej roboty”, zepsute, z blachy, z cyny warte łącznie 57 kop. Spośród wspomnianych 13 najtańszych przedmioty znajdowały się na 10/107 pozycji inwentarza, licząc 23/393 sztuki. Były to: blaszana latarka, pięć filiżanek, młynek do kawy, dwa „ordynaryjne” koszyki, ,pulwersak” i dwa rogi, młoteczek, pilniczek, świderek, szczypczyki, pieczątka, dwie laski laku, popsuty scyzoryk „w macicę oprawny", cynowa kropielniczka, tacka blaszana, szczypce. Tania odzież znalazła się na 3/34 pozycji inwentarza, licząc też trzy rzeczy jednocześnie stare: napierśnik morowy, pantofle i siennik.

W 25/141 pozycji inwentarza widnieją ruchomości określone jako stare. Łączna ich liczba to 52/393 sztuki na co składa się 11 przedmiotów i 41 sztuk odzieży, co stanowi $13 \%$ sztuk wszystkich ruchomości zawartych w inwentarzu. Na 10 pozycjach występują wśród przedmiotów: krzesełko popsute z wysoką poręczą, łóżko politurowane, dwa lichtarze mosiężne, parasol, stół kuchenny, żelastwo, zrośnięte kartofle, brzytwa, srebrna tabakiera, młynik do zboża. Na 15 pozycjach występują wśród ubrań: płaszcz „szaraczkowy” z futrem „szopowym”, sutanna z futrem zwanym „kasztany”, czarny zniszczony surdut, szlafrok barchanowy, spodnie ,szaraczkowe”, dwie kamizelki, czapka z futra bobrowego, dwa kapelusze, napierśnik „morowy”, trzy pary butów, 18 sztuk koszul płóciennych, 6 koszul sztuk podartych, pantofle, kołdra, siennik. Nie wszystkie stare rzeczy były jednak najtańsze. $Z$ wyżej wymienionych w grupie rzeczy drogich znalazła się: tabakiera, młynik, czapka (3 rb.), płaszcz (20 rb.), sutanna (12 rb.), 18 koszul (4,5 rb.). W inwentarzu tylko raz pojawia się określenie „nowy” w przypadku piłki ręcznej.

\section{Podsumowanie}

Podział rzeczy w inwentarzu jest uproszczony. Nie wydzielono kategorii surowcowych. Opisane przedmioty możemy podzielić według funkcji na ruchomości o charakterze kancelaryjno-gościnnym, sypialniano-garderobianym, kulinarno -spiżarnianym, gospodarczo-ogrodniczym.

Mienie proboszcza z Męki liczyło łącznie 393, a po pominięciu ruchomości gospodarskich 366 sztuk przedmiotów zamieszczonych na 141 pozycjach inwentarza. Liczba rzeczy plebana z Męki jest półtora raza mniejsza od ruchomości miejskiego rzemieślnika z połowy XIX wieku (599), jednocześnie niemal trzy razy

\footnotetext{
${ }^{101}$ Główka, Majątek, s. 199.

${ }^{102}$ Uwzględniono jako najtańsze wszystkie rzeczy z pozycji wycenionej na kilka kopiejek.
} 
większa od inwentarza okolicznego dziekana z początku XIX wieku (129) oraz ponad trzy razy większa od ruchomości plebanów okresu staropolskiego (108).

$\mathrm{W}$ porównaniu z zamożnym miejskim rzemieślnikiem ruchomości plebana z Męki przedstawiały się dość skromnie. Ks. A. Chyliński miał ponad cztery razy mniej mebli, trzy razy mniej garderoby, jedynie zastawy stołowej nieco więcej niż zamojski rękawicznik. Proboszcz ten posiadał jednak dwa razy więcej garderoby oraz trzy razy więcej mebli i zastawy stołowej niż plebani staropolscy oraz podobną liczbę mebli, niemal pięć razy więcej garderoby, ponad dwa razy więcej sztuk zastawy stołowej niż wspomniany dziekan. Inwentarz z $1862 \mathrm{r}$. zawierał też nieco mniej srebrnych łyżek w stosunku do porównywanych przykładów oraz zaledwie dwa obrazy.

Skromne wnętrza pomieszczeń były typowe dla wiejskich plebanii ${ }^{103}$. Za przejaw luksusu można uznać wyroby ze srebra i porcelany. Pleban mieszkał na plebanii z matką i być może ze służbą, co wpłynęło za liczbę zastawy. Większa liczba niektórych przedmiotów w posiadaniu plebana z Męki (przy porównaniu z przykładami z okresów wcześniejszych) może być związana z ich produkcją na szerszą skalę w XIX wieku, a przez to łatwością dostępu przy przystępnej cenie. Przy porównaniu inwentarza ks. A. Chylińskiego z mieniem ruchomym zamożnego rzemieślnika miejskiego $\mathrm{z}$ tego samego okresu dobytek proboszcza nie wypada już zbyt imponująco, wyraźnie ustępując zasobnemu mieszczaninowi.

Najdroższe ruchomości A. Chylińskiego warte od 3 do 28 r. liczące 59/393 sztuki stanowiły $15 \%$ sztuk rzeczy w inwentarzu. Wartość wszystkich kosztowności wynosiła niemal tyle co najdroższa krowa, która była najcenniejszym - obok płaszcza z futrem szopowym oraz pozłacanego łańcucha - składnikiem majątku zmarłego. Najtańsze przedmioty o wartości od 3 do 6 kopiejek liczyły łącznie sztuk 26/393, czyli $6 \%$ sztuk wszystkich ruchomości zawartych w inwentarzu. Wśród nich znajdowały się rzeczy stare i ,prostej roboty”, zepsute, z blachy, $\mathrm{z}$ cyny. Rzeczy drogich było ponad dwa razy więcej niż tanich.

Piętno właściciela jest zapisane $\mathrm{w}$ ocenie stanu zużycia przedmiotu ${ }^{104}$. Stan zachowania przedmiotów ${ }^{105} \mathrm{~W}$ większości był, jak należy wnioskować $\mathrm{z}$,milczenia źródła”, dobry. Jedynie część rzeczy była „stara”, co świadczyć mogło o ich długotrwałym użytkowaniu, a jednocześnie o rzadkiej wymianie/zastępowaniu. Ruchomości określone jako „stare” liczyły 52/393 sztuki, tj. 11 przedmiotów i 41 sztuk odzieży, co stanowi 13\% sztuk ogółu. Większa ich reprezentacja wśród garderoby wiązała się $\mathrm{z}$ widocznym zużyciem tkanin w skutek ich noszenia przez właściciela. Niektóre jednak nadal zachowywały wartość. Przedmiot „stary” nie był zawsze tani. W przypadku garderoby w grupie drogich „starych” znalazły się: czapka, płaszcz, sutanna, 18 koszul. Trzeba jednak pamiętać o innym możliwym znaczeniu określenia ,stary” jako niemodny, staroświecki ${ }^{106}$. W dwóch przypadkach mamy jednak dowód, że chodzi o zły stan - stare krzesełko było popsute, surdut zniszczony.

\footnotetext{
${ }^{103}$ Piątkowski, Niektóre, s. 354.

${ }^{104}$ Danowska. O rzeczach, s. 108.

${ }^{105}$ Klonder, Główka, Inwentarze, s. 173.

${ }^{106}$ Główka, Majątek, s. 55.
} 
Obraz „świata rzeczy” plebana z Męki nie jest pełny, bo zapewne nie wszystkie jego ruchomości trafiły do spisu ${ }^{107}$. Właściciel mógł część dobytku wcześniej rozdać ${ }^{108}$. Nawet podczas spisu niektóre przedmioty przekazano służącej (poduszkę i koszule) i bratu (okulary, brzytwę z paskiem do jej ostrzenia). Część ruchomości mogła na plebanii należeć choćby nominalnie do matki księdza, która przeżyła go o dwa dni ${ }^{109}$, stąd tym bardziej pośmiertny inwentarz jest niepełny i nie przedstawia kompletu przedmiotów, którymi otaczał się duchowny. Wyposażenie wnętrz należałoby uzupełnić o mobilia (utensylia) należące na stałe do probostwa.

Próby porównania niniejszego inwentarza z wynikami prac innych badaczy mają jedynie charakter wybiórczy i sondażowy. Ustalenie prawidłowości dotyczących wielkości majątku osobistego plebanów wiejskich w połowie XIX wieku wymagałoby szerokiej kwerendy źródłowej. Niniejsze „studium przypadku” jedynie sygnalizuje możliwości badawcze źródła o charakterze świeckim, jakim są akta notarialne dotyczącego majątku osobistego duchownych.

\section{REFERENCES / BIBLIOGRAFIA}

\section{Źródła rękopiśmienne}

Archiwum Diecezjalne we Włocławku

Akta diecezji kujawsko-kaliskiej, Archiwum Konsystorza Generalnego Włocławskiego, Akta personalne, Akta ks. Andrzeja Chylińskiego (1799-1862); Akta parafialne, sygn.

A. par. Męka 7.

Archiwum Państwowe w Łodzi

Akta stanu cywilnego Męka, sygn. 112.

Archiwum Państwowe w Łodzi oddział Sieradz

Akta notariusza A. Pstrokońskiego w Sieradzu, sygn. 4; Akta notariusza J. Sikorskiego w Szadku, sygn. 8.

\section{Źródła drukowane}

Inwentarze mieszczańskie z lat 1528-1635 z ksiag miejskich Poznania, wyd. S. Nawrocki, J. Wisłocki, Poznań 1961.

Kitowicz Jędrzej, Opis obyczajów i zwyczajów za panowania Augusta III, t. 1, wyd. E. Raczyński, Poznań1840.

Kobierzycki Józef, Przyczynki do dziejów ziemi sieradzkiej. Cz. 1, Warszawa 1915.

Ordo divini offici ad usum dioecesis Vladislaviensis seu Calissiensis pro anno domini 1859 ..., Warszawa [1858].

Ordo divini offici ad usum dioecesis Vladislaviensis seu Calissiensis pro anno domini $1862 \ldots$.. Warszawa [1861].

Stownik gwar polskich, wyd. J. Karłowicz, t. 1, Kraków 1900.

\footnotetext{
${ }^{107}$ Klonder, Główka, Inwentarze, s. 162.

${ }^{108}$ Piątkowski, Niektóre, s. 345.

${ }^{109}$ APŁ, ASC Męka, sygn. 112, Akt zgonu nr 44.
} 
Słownik języka polskiego, red. J. Karłowicz, A.A. Kryński, W. Niedźwiedzki, t. 1-8, Warszawa 1900-1923.

Szykuła Agnieszka, Inwentarz rękawicznika z Zamościa Józefa Serwetowicza z roku 1857, „Kwartalnik Historii Kultury Materialnej”, 56 (2008) nr 2, s. 219-226.

\section{Opracowania}

Brzeska Agnieszka, Inwentarze wypraw ślubnych kobiet z rodu Jagiellonów jako źródło do poznania wyposażenia wnętrz dworskich, „Kwartalnik Historii Kultury Materialnej", 56 (2008) nr 1, s. 3-18.

Chodyński Antoni Romuald, Obyczajowość polska w świetle inwentarzy Czapskich $z$ XVIII w., „Kwartalnik Historii Kultury Materialnej”, 51 (2003) nr 2, s. 277-291.

Danowska Ewa, O rzeczach doczesnych księdza kanonika. Inwentarz pośmiertny Michała hrabiego Ankwicza z 1786 r., „Nasza Przeszłość”, 110 (2008) s. 107-128.

Doroszewski Witold, Słownik języka polskiego, t. 1-11, Warszawa 1958-1969 [wersja elektroniczna].

Główka Dariusz, Majątek osobisty duchowieństwa katolickiego w Koronie w XVII i XVIII wieku, Warszawa 2004.

Ihnatowicz Ireneusz, Biernat Andrzej, Vademecum do badań nad historia XIX i XX wieku, Warszawa 2003.

Jakubowski Włodzimierz, Ordery i medale Rosji, Toruń 1993.

Klonder Andrzej, Główka Dariusz, Inwentarze mienia w badaniach kultury Europy od średniowiecza po nowożytność, „, Kwartalnik Historii Kultury Materialnej”, 51 (2003) nr 2, s. 157-176.

Kujawski Witold, Kościelne dzieje Sieradza, Włocławek1998.

Kujawski Witold, Diecezja kujawsko-kaliska. Opracowanie historyczno-źródłoznawcze, Włocławek 2011.

Kujawski Witold, Parafie diecezji włocławskiej. Okres kujawsko-kaliski 1818-1925. Dla upamiętnienia 90. rocznicy powstania Towarzystwa Teologicznego we Włocławku, Włocławek 2018.

Lewalski Krzysztof, Inwentarz mienia - źródło do badań nad majątkiem osobistym duchowieństwa parafialnego w Królestwie Polskim na przełomie XIX i XX w., „Kwartalnik Historii Kultury Materialnej”, 65 (2017) nr 2, s. 257-266, https://rcin.org.pl/ dlibra/show-content/publication/edition/63963?id $=63963$.

Mazur Elżbieta, Wykorzystanie inwentarzy w badaniach nad kultura XIX wieku na ziemiach polskich, „Kwartalnik Historii Kultury Materialnej”, 51 (2003) nr 2, s. 177 182.

Moczulska Agnieszka, Inwentarze, protokoty licytacji, intercyzy $i$ testamenty zawarte $w$ aktach notarialnych z obszaru Królestwa Polskiego w XIX wieku, „Studia Źródłoznawcze", 22 (1977) s. 217-224.

Mohrmann Ruth-E., Pośmiertne inwentarze mienia - krytyka źródła, problemy badawcze, „Kwartalnik Historii Kultury Materialnej”, 53 (2005) nr 2, s. 137-146.

Piątkowski Sebastian, Niektóre elementy wyposażenia plebanii we wsi i miasteczku pótnocnej Małopolski w pierwszej połowie XIX wieku, ,Studia Sandomierskie”, 9 (2002) s. 343-354.

Szkutnik Piotr, Siedziby dziekanów dekanatu brzeźnickiego w diecezji kujawsko-kaliskiej $w X I X w .$, Kwartalnik Historii Kultury Materialnej”, 59 (2011) nr 2, s. 167-181.

Szkutnik Piotr, Testament mieszczanki szadkowskiej Doroty Czygańskiej z Lipińskich z 1693r., „Biuletyn Szadkowski”, 14 (2014) s. 97-112, http://biuletynszadkowski.geo. uni.lodz.pl/uploads/art/2014/7\%20Piotr\%20\%20Szkutnik.pdf. 
Szkutnik Piotr, Utensylia w kancelarii dziekana brzeźnickiego w pierwszej połowie XIX w, „Archiwista Polski”,19 (2014) nr 3, s. 23-30.

Szkutnik Piotr, Ksiądz Michat Mieczko Żdzenicki (1744-1814) proboszcz i dziekan szadkowski, „Przegląd Nauk Historycznych”, 14 (2015) nr 1, s. 173-191, http://bazhum. muzhp.pl/media//files/Przeglad_Nauk_Historycznych/Przeglad_Nauk_Historycznych-r2015-t14-n1/Przeglad_Nauk_Historycznych-r2015-t14-ñ1-s173-191/Przeglad_Nauk_Historycznych-r2015-t14-n1-s173-191.pdf.

Szkutnik Piotr, [rec.] Duchowni na plebanii i w drodze. Konteksty codzienności i interpretacje historyczne, red. K. Lewalski, A. Łysiak-Łątkowska, Gdańsk 2015, „Archiwa Biblioteki i Muzea Kościelne", 110 (2018) s. 507-517.

Szykuła Agnieszka, Dwory ziemiańskie i garderoba ziemianek Zamojszczyzny na podstawie inwentarzy notarialnych z lat 1835-1876, , Kwartalnik Historii Kultury Materialnej”, 56 (2008) nr 1, s. 19-29.

\title{
THE 1862 INVENTORY OF MOVABLE PROPERTY OF FR. ANDRZEJ CHYLIŃSKI, THE PARISH PRIEST OF THE MĘKA PARISH IN THE SIERADZ DEANERY
}

\begin{abstract}
Father Andrzej Chyliński was the parish priest in the village of Męka near Sieradz, where he lived with his mother and possibly with several servants. Compiled after his death in 1862, the inventory separates the movable property he had owned into two categories, without distinguishing the raw material.

The movable property listed on the inventory were used for office, leisure, wardrobe, culinary, pantry and utility functions. The majority of the mobile property was situated in the alcove room. The property of the parish priest of Męka amounted to a total of 393 pieces. Upon excluding farm movables, these were 366 pieces listed as 141 inventory items.

A comparison of the personal property of the Męka parish priest with the local dean from the beginning of the 19th century (129 pieces in total) and average Old Polish parish priests (108 pieces) demonstrates a significant quantitative advantage in most types of movable property. However, the opposite can be observed when comparing A. Chyliński and his movables with a wealthy city craftsman from Zamość in the mid-19th century (599 pieces). The most expensive movables in the 1862 inventory accounted for $15 \%$ of items, whereas the cheapest constituted $6 \%$ of all items. Thus, Chyliński owned more than twice as many expensive items as cheap items. Items described as 'old' constituted $13 \%$ of the total amount.
\end{abstract}

Keywords: inventory; movable property; clergy; Fr. Andrzej Chyliński; the Mecka parish; the Sieradz deanery; 19th century 